\title{
The common challenges of south-east European countries in the process of European integration
}

\begin{abstract}
This article comprehensively discusses the common challenges of south-east European countries in the process of European integration. It will look into the impacts of the euro crisis in south-east countries including Montenegro, Croatia, BosniaHerzegovina, Serbia, Macedonia and Albania. The article also discusses the importance of collaboration and co-ordination in the Balkans region for the future of these countries in the European Union. From the point of view of both the European Union and the countries of south-east Europe, the region requires integration in or, at least, being closely linked to the European Union. This would be an essential step towards the establishment of a framework for economic, legal and political stability, cross-border co-operation and internal reforms among the countries. It is clear that the process of integration with the European Union has faced numerous and significant challenges over the years. The first set of challenges remains the Balkans itself; the second rests with the parent continent (Sergi and Qerimi, 2008: 1).
\end{abstract}

Keywords: European Union, enlargement, western Balkans, Stabilisation and Accession Process, integration, democratisation, instability, governance, economic development, co-ordination, globalisation

\section{Introduction}

The recent extension of the European Union beyond its customary western-oriented confines has, quite radically, made it a more heterogeneous and wider institution. In regard to the states of the western Balkans, the European Union has a great opportunity to change the European geopolitical context by offering them full membership. Enlargement policy can serve as a substantial tool with which the Union may promote its presence in the international context and effectively boost its foreign policy (Radosevic, 2009: 638).

There have, however, been significant signs of a backsliding on the part of the European Union in recent times. This article comprehensively presents the case for the complete absorption of the region of the western Balkans in the European Union, including meeting the challenges and recognising the importance of collaboration and co-ordination in the Balkans region to their future within the European Union. If integration is to happen successfully and effectively, not only the European Union but also the entire western Balkans region would benefit in respect to improved prosperity and stability in the post-Cold War era (Rohrschneider and Whitefield, 2007: 1141).

The end of the Cold War and the idea of a common pursuit of prosperity under stable democratic governance have significantly resulted in the expansion of the Euro- 
pean Union with the addition of the countries of the Baltic region and those from eastern and central Europe. The region of the western Balkans is integrally bound to Europe, but it has normally been on the sidelines of the concerns of the European Union, with attention mainly given to the region only in the event of violent changes or conflicts (Marks et al. 2006: 167). The western Balkans region has always had attributed to it a low level of development, as well as a position of strife both between and within its countries.

\section{Background}

The transition from substantially directed economies to south-east Europe market economies has significantly led to rampant collapse in respect of output in all the nations of the region as well as, in the case of the former Yugoslavia, ethnic strife and disintegration. This has brought about extra burdens which have had adverse implications for the entire region. Economic transition has required parallel movements with regard to efforts towards restoring political-social stability and peace (Anastasakis, 2005: 83). Various poorly co-ordinated and unrealistic international initiatives for the region as a whole have proved fruitless.

The demoralising blow to the Union's image from its Balkans engagement in the 1990s drove home the requisite for acting assertively and positively towards the region. The Union's initiation of its European Accession Partnerships, and then the Stabilisation and Association Process (SAP) of the 2000s, affirmed significant commitments to the region and a determination to seek authentic reforms for prospective candidates, acknowledged as such by both governments and people (Qorraj, 2010: 88). This evidenced a catalyst of regional change.

In the light of this, the European Union initiated the SAP in 1999 with the then five western Balkans states, including Montenegro, Croatia, Bosnia-Herzegovina, Serbia and Albania, as a key step towards instituting a long-term approach and advance across the region. The Union held out to the western Balkans countries the prospect of European Union membership for the first time in their history. The SAP was intended to assist countries within the region progress closer to the Union through introducing European principles, standards and values across the region. These include the rule of law, democracy, a market economy, protection of minorities and respect for human rights. In addition, the goal of the SAP was the conclusion of a Stabilisation and Association Agreement (SAA) in each case, binding western Balkans nations and the European Union into a formal association throughout the period of the transition. The SAP involved exhaustive assistance and support through technical guidance aimed at better governance; the democratisation process; protection for human rights; effective institution building; refugee welfare; the eradication of organised crime and corruption; and economic development (Noutcheva and Aydin-Düzgit, 2012: 64).

The European Union has a considerable moral obligation to help countries within the region, as well as an interest in their economic and political stability. The Treaty on the European Union states that any state in Europe that fulfils its basic principles can apply for membership. The states of the western Balkans have always been an essential part of Europe, but they have hardly received an appropriate level of attention and now appear as a discrepancy in the map of the European Union following the 
accession of Romania and Bulgaria in 2007. Croatia gained membership of the European Union in 2013, having successfully negotiated all the chapters of the acquis, and having portrayed the kind of ability and commitment to pursue the reform agenda of European Union integration which east and central European countries had indicated in the 1990s (Demetropoulou, 2002: 96). Croatia had hoped to join in 2007 but, negotiations proving tougher than expected, its date of accession was not endorsed until mid-2011. The region's other countries, in contrast, have always been given only vague promises of joining the European Union in the future.

During the past decade, European Union policy towards the western Balkans has improved drastically. The European Union visualises each nation as an essential part of the entire region, recognising the common denominators of problems which, in some cases, need collective solutions without losing sight of a country's specificities. The regional approach thus significantly co-exists with the specific approach made to each country (Brown and Attenborough, 2007: 5). The main problems or issues are related to the need to strike a balanced deal between these objectives, as well as distributing funds accordingly with consideration of the limited resources available after the last enlargement of the European Union.

With the eastern enlargement ultimately having taken place, the prospects of the accession of the western Balkans countries appeared to have significantly dimmed due to the existence of various factors. Nevertheless, the European Union had established a process of accession for most western Balkans states (Trauner, 2009: 785); the SAA with Albania was signed in 2009, while negotiations were commenced with Serbia, Montenegro and Bosnia-Herzegovina, the former two resulting in the signing of SAAs in 2013 and 2010 respectively, while an interim agreement is still in force, having been signed in 2008, in the latter.

Observers have the opinion that the enlargement of the European Union to eastern and central Europe was both effective and successful. It brought to a close the legacy of conflict in this region and gave the countries the required impetus for their economic and political modernisation, bringing security and stability to a large part of the European continent. The fundamental value of European integration was, therefore, significantly re-affirmed as a result (Inotai, 2007: 256). There is a compelling reason for pursuing the goals of the integration of the western Balkans within the Union if stability, prosperity and democratisation are to be accomplished in a major part of Europe without having to have recourse to isolated foreign policy initiatives.

Nevertheless, there are regionally-based challenges which remain and which substantially refer to:

1. the high-level of human and institutional destruction of the last decade of the twentieth century

2. a slow process of institutional reform, along with a lack of visionary, principled policies and commitment among the regional leaderships (Sergi and Qerimi, 2008: 20). 


\section{Major issues and challenges}

\section{Civil and political instability}

Despite the numerous accomplishments and efforts, the region of the western Balkans is still faced with various pressing structural problems in the political, economic and institutional spheres. These include constitutional uncertainty; open status issues; poverty; high rates of unemployment; a poor business environment; and 'weak state' syndrome (Qorraj, 2010: 88). The International Commission on the Balkans (2005: 7) believed that the region was as close to failure as it was to success.

Even after a decade had passed subsequent to the end of the Bosnian war, the efforts of building peace within the region had still yet to find a solid foundation. State-building was largely incomplete and constitutional uncertainty remained in existence. For instance, national constitutions significantly lacked acceptance among both the ruling elite and the citizens at large.

People's uncertainty in respect of the future political framework within the region generates nationalism and scepticism vis-à-vis the process of reform, accompanied by violence and instability (Marks et al. 2006: 173). One of the challenging objectives in the region is, significantly, the establishment of democratic and stable government.

Reports have shown that the rule of law and democracy are making uneven and slow advances across the western Balkans. There continues to be a conspicuous absence of transparency and stability in government; weak protection for the rights of minority and ethnic groups, set against a resurgent appeal of ultra-nationalism and extremism in some countries; low government receptivity to participation by citizens; economic and political media pressures; and a pervasive whiff of corruption across all levels of government and society. Additionally, civil society is still highly under-developed and, mainly, reliant on external donors for its funding and, indeed, survival (Rohrschneider and Whitefield, 2007: 1144). The region's countries are, after all, moving in the right direction, but they are still far from reaching the position of those east and central European countries that joined the European Union in the middle of the last decade.

\section{Low levels of economic development}

With regard to economics, the growth of GDP in most of the region has been very sluggish. Levels of GDP that were in place before the start of the war within the region still remain, in large part, to be overtaken. In addition, war, quick privatisation and sanctions have resulted in the collapse of industries in many western Balkans countries, which has led to increased poverty and unemployment. The latter problem continues to haunt a significant proportion of the population, while living standards are below the poverty line for many citizens. The informal sector plays a key role in these countries' economies, accounting for more than one-third of total income. This has led to significant increases in inequality and poverty as regards accessing services and opportunities.

There remains some optimism about economic prospects within the region, but western Balkans countries are still poorer compared to the rest of Europe and specifically eastern and central European nations (Noutcheva and Aydin-Düzgit, 2012: 77). Private businesses in the western Balkans reckon on various impediments, including 
the absence of a competitive framework; poor quality standards; lack of financial access; poor access to markets; and high taxes. Countries within the region tend towards corruption and the state continues to dominate many areas of public life.

\section{Shifts in the priorities of foreign policy as well as shrinking aid}

The European perspective incorporates a powerful incentive for reforms and conflict resolution within the region of the western Balkans. All the countries in the region have significantly invested increased effort in the process of reform. Such progress runs the serious risk of being thwarted due to new security concerns on the part of the international community and to the increased pressure arising from scarce resources. For instance, NATO has significantly reduced its conflict resolution presence in the Balkans, foreign assistance has greatly declined and much of the political attention has shifted to blazing spots in the Islamic world (Liebscher, 2005: 409). Financial assistance from the international donor community has been on the decline in recent years.

\section{The debate on enlargement}

There has been an increasing level of debate among the members of the European Union. This includes the fear that inclusion within the Union could bring some protracted conflicts into Europe, as well as a factor often referred to as 'enlargement fatigue', a term which has come significantly into vogue, in which the capability of the European Union to accommodate increased numbers of member countries is seriously questioned. In fact, many European Union member states oppose the enlargement of the European Union to include south-east Europe. Much of this opposition is caused by fears among member states of low-cost competition as well as immigration. Besides 'enlargement fatigue', the notion of 'privileged partnerships' and 'junior partnership status' is another debate that is going around as the Union's membership explores alternatives to enlargement to the south-east (Inotai, 2007: 274). Support for the Union's enlargement to south-east Europe varies immensely from country to country among the member states.

\section{The importance of collaboration and co-ordination within the Balkans region for countries' futures in the European Union}

In respect of closer association between the European Union and states in the region of the western Balkans region, substantial progress has been made, especially in the area of regional co-operation. This includes the successful formation of an energy community, the regional free trade agreement and the Central European Free Trade Agreement. This has been particularly significant for the empowerment and development of the entire region. Through this effort, the participating states have undertaken various credible initiatives, including the liberalisation of their trade regimes. Significant progress has been taken on settling refugee issues; improving the investment and business climate; fighting corruption and organised crime; developing regional infrastructure strategies; and creating a common energy market (Liebscher, 2005: 361). This shows that continued collaboration and co-ordination in the Balkans region for their future within the European Union carries enormous benefits for the region as a whole. 
The integration of south-east Europe in the European Union could be a success story for the European Union and Europe as a whole. It would help to overcome the division of Europe and also contribute to stability and regional peace across the continent. Successful integration would significantly inspire reforms and enhance the regard that the whole continent holds for the consolidated common principles of democracy, liberty, respect for fundamental freedoms and human rights, the rule of law and the market economy. The enlargement of the European Union to include south-east Europe would ensure wider internal markets and economic co-operation, which would increase prosperity and competitiveness (Qorraj, 2010: 90). This has enabled the enlarged Union to respond more effectively to the ever-emerging challenges of globalisation. Enlargement would also enhance the Union's weight in the world and turn it into a stronger international partner. The future of the western Balkans lies in the European Union.

The prospect of European Union membership will continue to be the most effective means of ensuring good neighbourly relations and stability in the western Balkans. This will function as a mechanism for initiating and sustaining reforms and will also offer a platform for creating a strong framework for regional co-operation and conflict resolution. The prospect of enlargement is the most essential foreign policy instrument with which the European Union has spread and promoted external and internal democracy, security, economic development, reforms and prosperity within the former communist states of eastern, southern and central Europe (Radosevic, 2009: 646). It has assisted, and will continue to help, in the guarantee and consolidation of the transition process, ensuring that state collapse and ethnic conflicts are avoided.

In order to establish an equilibrium aiming at reconciling these stages of the process, Sergi and Qerimi (2008) proposed a 'Four I system' that serves as a principal guideline, namely: information; interaction; incentives; and institutions. These elements are critical for a better, easier and quicker integration path.

Even as financial assistance from the international donor community declines, European Union member states will increasingly become the single largest donor in south-east Europe through providing humanitarian assistance and aid for economic development. The European Union would become significantly involved in the economic development of this region following successful integration, through providing crisis management, capacity building, reconstruction and assistance in the process of reforms, as well as the offer of a membership perspective. These efforts would result in greater and increased stability within the region, in addition to the consolidation of state structures (Demetropoulou, 2002: 103). The result of the Union's unique position is that integration with the EU would increasingly harness significant support across the region for its stable and democratic future through the goal of European Union approximation as well as the provision of financial assistance towards this end.

\section{Conclusion}

If the European Union is to continue playing an instrumental and crucial role in designing the eventual post-cold war order of Europe, then it should hold out a clear membership prospect to this region of Europe, which remains embraced under the general banner of prosperity and stability. Through the innovative and dynamic policy of the Union's enlargement to include the western Balkans, the European Union should 
fully exploit its soft power of magnetic attraction as well as its anchoring capacity in order to help Balkans states resume their path back to Europe. The benefits of this policy could be clearly conspicuous for the European Union itself, for it would be in a position to strengthen its global muscles and expand its regional and global interests.

\section{References}

Anastasakis, O (2005) 'Europeanization of the Balkans' Journal of World Affairs 12(1): 77-88.

Brown, Adèle and Michael Attenborough (2007) EU Enlargement: the Western Balkans http://www.parliament.uk/briefing-papers/RP07-27 [last accessed 24 October 2013].

Demetropoulou, Leeda (2002) 'Europe and the Balkans: Membership Aspiration, EU Involvement and Europeanization Capacity in South Eastern Europe' Southeast European Politics III(2): 87-106.

Inotai, András (2007) The European Union and Southeastern Europe: Troubled Waters Ahead? Bruxelles: P.I.E. Peter Lang.

International Commission on the Balkans (2005) The Balkans in Europe's Future Centre for Liberal Strategies: Sofia, available at: http://www.cls-sofia.org/uploads /files/Projects\%20files/International\%20Commission\%20on \%20the\%20Balkans. pdf [last accessed 24 October 2013].

Liebscher, Klaus (2005) European Economic Integration and South-East Europe: Challenges and Prospects Cheltenham: Elgar.

Marks, Gary, Liesbet Hooghe, Moira Nelson and Erica Edwards (2006) 'Party Competition and European Integration in the East and West' Comparative Political Studies 39(2): 155-175.

Noutcheva, Gergana and Senem Aydin-Düzgit (2012) 'Lost in Europeanisation: The Western Balkans and Turkey’ West European Politics 35(1): 59-78.

Qorraj, Gazmend (2010) 'Integrating the Western Balkans into the European Union: Overcoming Political and Economic Constraints' European Perspectives - Journal on European Perspectives of the Western Balkans 2(2): 79-92.

Radosevic, S (2009) 'Research and Development, Competitiveness and European Integration of South Eastern Europe' Europe-Asia Studies 61(4): 621-650.

Rohrschneider, Robert and Stephen Whitefield (2007) 'Representation in New Democracies: Party Stances on European Integration in Post-Communist Eastern Europe' The Journal of Politics 69(4): 1133-1146.

Trauner, Florian (2009) 'From membership conditionality to policy conditionality: EU external governance in South Eastern Europe' Journal of European Public Policy 16(5): 774-790.

Sergi, Bruno and Qerim Qerimi (2008) The political economy of Southeast Europe from 1990 to the present Bloomsbury. 